\title{
Genetic parameter and correlation estimates of processing traits in half-sib progenies of tropical-adapted carrot germplasm
}

\author{
Jairo V Vieira; Giovani Olegario da Silva*; Leonardo S Boiteux \\ Embrapa Hortaliças, C. Postal 218, 70351-970 Brasília-DF, Brazil; *Corresponding author; jairo@cnph.embrapa.br; olegario@cnph. \\ embrapa.br; boiteux@cnph.embrapa.br
}

\begin{abstract}
The estimate of the genetic parameters associated with processing (fresh-cut) traits, including root length (RL), is crucial for carrot breeding programs in tropical areas. The cultivar Alvorada is an important germplasm due to its resistance to nematodes, leaf blight, heat-tolerance, and high carotenoid content. Seventy-four 'Alvorada' half-sib progenies were evaluated during the summer of 2005 in the Federal District, Brazil, in a randomized complete block design with three replications. Thirteen competitive plants in each block were randomly selected and evaluated and/or classified for RL and for number of leaves (NL), leaf length (LL), root tip type (RT), root mass (RW), crown shape (CS), root diameter (RD), and xylem diameter (XD). The Pearson's correlation coefficients and the heritability values were estimated for all traits. The path analysis was also used considering the RL trait as dependent variable. The heritability for RL ranged from 12 to $44 \%$. For the other traits, the values ranged from 3\% (RD) to 79\% (LL). Phenotypic and genotypic correlations among all traits were low to intermediate. Path analysis indicated positive direct relationship between RL and RW, whereas RD and $\mathrm{XD}$ displayed negative direct effect on RL. Longer roots had narrow diameter and narrow XD. Recurrent selection based upon either half-sib or $\mathrm{S}_{1}$ families would be more effective than mass phenotypic recurrent selection in increasing $\mathrm{RL}$ and to develop populations expressing multiple desirable processing traits in tropical-adapted carrot germplasm.
\end{abstract}

Keywords: Daucus carota, heritability, genetic correlation, path analysis, root length.

\section{RESUMO}

Parâmetros genéticos e correlações entre características para processamento em progênies de meios-irmãos de germoplasma de cenoura tropical

A estimativa de parâmetros genéticos associados com caracteres de processamento industrial, incluindo comprimento de raiz (RL), é crucial para programas de melhoramento de cenoura para áreas tropicais. A cultivar Alvorada é um importante germoplasma devido à sua resistência a nematóides e queima-das-folhas, tolerância ao calor e alto conteúdo de carotenóides. Setenta e quatro progênies meio-irmãs derivadas de 'Alvorada' foram avaliadas durante o verão de 2005 no Distrito Federal (DF), em blocos casualizados com três repetições. Treze plantas competitivas em cada bloco foram selecionadas ao acaso e avaliadas ou classificadas para RL, número de folhas (NL), comprimento de folhas (LL), tipo de ponta de raiz (RT), massa de raiz (RW), formato do ombro da raiz (CS), diâmetro da raiz (RD) e diâmetro do xilema (XD). Foi estimada a correlação de Pearson entre os caracteres, realizada a análise de trilha considerando RL como a variável dependente; o coeficiente de herdabilidade e outros parâmetros genéticos. Os valores de herdabilidade para RL variaram entre 12 e $44 \%$. Para os outros caracteres, os valores variaram de $3 \%$ (RD) a $79 \%$ (LL). Os valores observados para as correlações fenotípicas e genotípicas entre todos os caracteres variaram de baixos a intermediários. A análise de trilha indicou efeito positivo para a relação entre RL e RW, muito embora RD e XD tivessem efeitos diretos negativos em RL. Maiores raizes apresentaram menores diâmetros e menores XD. Métodos de seleção recorrente baseados em meio-irmãos ou famílias $S_{1}$ podem ser mais efetivos que seleção recorrente fenotípica massal no aumento de RL e no desenvolvimento de populações com caracteres desejáveis para o processamento em germoplasma de cenoura tropical.

Palavras-chave: Daucus carota, herdabilidade, correlação genética, análise de trilha, comprimento de raiz.

(Recebido para publicação em 29 de julho de 2010; aceito em 10 de outubro de 2011) (Received on July 29, 2010; accepted on October 10, 2011)

$I^{2}$ the Northern Hemisphere, the dietary contribution of carrot (Daucus carota) as a source of provitamin A carotenoids was increased after the entry into the market of a new class of raw snack products, the so-called 'baby-carrots', during the decade of
1990 (Lucier \& Lin, 2007). In Brazil the production of this kind of products is also increasing. Along with the development of fresh-cut processing 'baby carrots' came a renewed stimulus for breeding programs to improve root shape, texture, flavor, and orange color (and as consequence provitamin A content) (Simon et al., 2008). These ongoing efforts resulted in the release of several provitamin A improved breeding populations and cultivars (Simon, 2000; Vieira et al., 2005; Luz et al., 2008; Simões et al., 2010). 
The carrot crop is also expanding its acreage, yield as well as per capita consumption in several tropical and subtropical areas of the world (Simon et al., 2008). However, most of the nutritionally improved carrot breeding materials developed in the Northern Hemisphere have poor adaptation to high temperatures and low soil fertility present in many tropical agroecosystems as well as very low levels of resistance to tropical diseases. The development of carrot cultivars with adaptation to warm, lowland tropical areas has been one of the major breeding efforts conducted in Brazil (Silva et al., 2010). The cultivar Brasília (Vieira et al., 1983) was the most important release of the Embrapa Vegetables carrot breeding program, which started in 1981. Soon after 'Brasília' became the leading cultivar for summer season cultivation in tropical and subtropical areas of the country. This market dominance was mainly due to its high-yielding potential, heat tolerance, and high levels of resistance to leaf blight complex allowing cultivation during the rainy/ hot season with very low agrochemical input (Boiteux et al., 1993; Vilela, 2008).

The 'Brasília' release, along with improvements in the crop management system, was responsible for the increase of over $150 \%$ in Brazilian carrot production. More recently, two new cultivars named 'Alvorada' and 'Esplanada' (Vieira et al., 2005) were developed using 'Brasília' as basic germplasm. 'Alvorada' has superior performance in relation to 'Brasília' in some important characteristics such as less incidence of green shoulder, higher levels of field resistance to root-knot nematode species (Meloidogyne spp.) (Vieira et al., 2003), and 35\% more (i.e. about $110 \mu \mathrm{g} / \mathrm{g}$ ) total carotenoids than 'Brasília'. These characteristics indicate that 'Alvorada' is a potentially useful germplasm resource for carrot breeding programs in other tropical areas of the world.

Genetic improvement of root length in tropical-adapted germplasm is one of the major bottle necks since no significant improvement (in comparison to 'Brasília') was obtained for root yield and root length during the development of 'Alvorada'. Therefore, a better understanding of genetic parameters associated with these traits in this germplasm is of paramount importance for breeding programs dealing with development of cultivars suitable for the fresh-cut processing industry. Determination of the heritability value of root length as well as the genetic association of this trait with other relevant quantitative traits are important pieces of information helping to define either the most effective breeding strategies, or to predict the expected improvement due to selection (Nyquist, 1991; Alves et al., 2004; Vilela, 2008; Silva et al., 2009). The main objectives of the present work were to estimate the heritability, phenotypic, and genotypic correlations among a set of quantitative traits and root length; to run a path analysis with traits genetically correlated to root length and to determine the expected gain from selection for this trait in progenies derived from the cultivar Alvorada.

\section{MATERIAL AND METHODS}

A total of 74 half-sib progenies was obtained from 'Alvorada'. These progenies were evaluated under field conditions during the rainy summer season (January-April) of 2005. The experiment was conducted at Embrapa Hortaliças in a randomized complete block design with three replications. Plots were $2 \mathrm{~m}^{2}$ beds with four rows (20 plants per row) spaced of 20 $\mathrm{cm}$. At the harvesting, a total of 13 competitive plants in each block was randomly selected and evaluated and/ or classified for the following traits: number of leaves (NL), leaf length (LL), root mass/weight (RW), root length (RL), crown shape (CS) using the grading system described in the Figure 1 , root tip type (RT) using the grading system described in the Figure 2, root diameter (RD) and xylem diameter (XD). Data set was analyzed using the procedure of randomized blocks with additional controls as described by Cruz et al. (2004). Pearson's correlation coefficients among the traits under evaluation were estimated and the path analysis, which was treated of a standardized partial regression, was done considering the RL trait as dependent variable. The establishment of the path analysis basic equations and the resolution in the matricial form was done via the system of normal equations, as follows: $\mathrm{X}^{\prime} \mathrm{X} \beta=\mathrm{X}^{\prime} \mathrm{Y}$, where $\mathrm{X}^{\prime} \mathrm{X}$ is a non-singular matrix of the correlations among the explanatory variables; $\beta$ is a vector-column of trial coefficients; and $X^{\prime} Y$ is a vector-column of the correlations between the explanatory variables and the main variable (Cruz et al., 2004).

\section{RESULTS AND DISCUSSION}

Significant differences were observed for six out of the eight traits under evaluation among families (data not shown). The genetic variance for RL that was observed within families was greater than that observed among families (Table 1). The heritability values for RL were intermediate to low (between 12\% and 44\%) depending upon the selection unit employed. In addition, these values of heritability suggest that exclusive employment of mass selection would not convert into considerable genetic advance for this trait (Table $1)$. This fact should be taken into consideration because RL is crucial trait in the current breeding programs aiming at the development of cultivars suitable for cut and peel processing industry in all carrot production areas. The results indicated that family structuring would be a more effective strategy than mass selection for genetic improvement of this trait. This notion is supported by the observation that the ratio between coefficient of genetic variation within families and the coefficient of genetic variation among families are larger than the coefficient of environmental variation (Table 1). It is important to mention that the value of the residual variance was very small indicating high environmental control in the experiment and consequently greater potential for advances in selection.

Comparing with previous reports in the literature, these values of heritability were, for example, smaller than the ones obtained by Natarajan \& Arumugan 
Table 1. Genetic parameter estimates for number of leaves (NL), leaf length (LL), root mass (RW), root length (RL), root diameter (RD), xylem diameter (XD), root tip (RT) and crown shape (CS) associated with the trait root length in 74 half-sib families derived from the cultivar Alvorada [parâmetros genéticos estimados para número de folhas (NL), comprimento de folhas (LL), massa de raízes (RW), comprimento de raiz $(\mathrm{RL})$, diâmetro de raiz $(\mathrm{RD})$, diâmetro de xilema $(\mathrm{XD})$, tipo de ponta de raiz (RT) e formato do ombro (CS), associados com a característica comprimento de raiz em 74 famílias de meios-irmãos derivadas da cultivar Alvorada]. Brasília, Embrapa Hortaliças, 2005.

\begin{tabular}{lrrrrrrrr}
\hline Parameters & \multicolumn{1}{c}{ NL } & \multicolumn{1}{c}{ LL } & \multicolumn{1}{c}{ RW } & RL & RD & \multicolumn{1}{c}{ XD } & RT & CS \\
\hline Maximum (family average) & 11.040 & 48.690 & 101.770 & 16.380 & 3.570 & 1.620 & 2.770 & 2.310 \\
Overall mean & 6.859 & 40.694 & 68.668 & 13.494 & 2.671 & 1.190 & 2.075 & 1.870 \\
Minimum (family average) & 5.040 & 33.150 & 42.850 & 11.120 & 2.130 & 0.830 & 1.580 & 1.540 \\
Genetic variance among families & 0.441 & 7.955 & 56.669 & 0.482 & 0.016 & 0.011 & 0.032 & 0.003 \\
Genetic variance within families & 1.323 & 23.865 & 170.007 & 1.445 & 0.049 & 0.033 & 0.095 & 0.009 \\
Phenotypic variance within families & 5.067 & 30.029 & 562.087 & 12.203 & 0.810 & 0.110 & 0.615 & 0.342 \\
Heritability (family average) (\%) & 58.920 & 76.580 & 58.670 & 43.580 & 31.170 & 61.710 & 47.000 & 16.790 \\
Heritability (within families) (\%) & 26.100 & 79.480 & 30.250 & 11.840 & 6.070 & 30.200 & 15.460 & 2.620 \\
CV environment among (CV1) (\%) & 6.915 & 3.928 & 8.812 & 4.114 & 3.756 & 6.097 & 7.489 & 3.084 \\
CV genetic among families (CV2) (\%) & 9.681 & 6.931 & 10.963 & 5.142 & 4.794 & 8.832 & 8.578 & 2.926 \\
CV genetic within families (CV3) (\%) & 16.768 & 12.005 & 18.988 & 8.907 & 8.303 & 15.298 & 14.857 & 5.068 \\
CV2/CV1 ratio & 1.400 & 1.765 & 1.244 & 1.250 & 1.276 & 1.449 & 1.145 & 0.949 \\
CV3/CV1 ratio & 2.425 & 3.057 & 2.155 & 2.165 & 2.211 & 2.509 & 1.984 & 1.643 \\
\hline
\end{tabular}

Table 2. Phenotypic (above bold diagonal) and genotypic (below bold diagonal) correlations among leaf and root traits: number of leaves (NL), leaf length (LL), root mass (RW), root length (RL), xylem diameter (XD) and root tip (RT), evaluated in 74 progenies from the cultivar Alvorada [correlação fenotípica (diagonal superior) e genotípica (diagonal inferior) entre caracteres de folha e raiz: número de folhas (NL), tamanho de folha (LL), massa de raiz (RW), tamanho de raiz (RL), diâmetro de xilema (XD) e tipo de ponta de raiz (RT) de 74 progênies a partir da cultivar Alvorada]. Brasília, Embrapa Hortaliças, 2005.

\begin{tabular}{lllllllc}
\hline & $\mathbf{N L}$ & $\mathbf{L L}$ & $\mathbf{R W}$ & $\mathbf{R L}$ & $\mathbf{R D}$ & $\mathbf{X D}$ & $\mathbf{R T}$ \\
\hline NL & $\mathbf{1 . 0 0 0}$ & $0.280^{*}$ & $0.283^{*}$ & $0.257^{*}$ & $0.259^{*}$ & -0.067 & 0.025 \\
LL & $0.333^{*}$ & $\mathbf{1 . 0 0 0}$ & 0.130 & 0.020 & 0.010 & 0.000 & -0.200 \\
RW & $0.451^{*}$ & 0.200 & $\mathbf{1 . 0 0 0}$ & $0.546^{*}$ & $0.557^{*}$ & $0.527^{*}$ & -0.150 \\
RL & $0.423^{*}$ & 0.040 & $0.507^{*}$ & $\mathbf{1 . 0 0 0}$ & 0.150 & 0.148 & -0.034 \\
RD & $0.287^{*}$ & 0.021 & $0.865^{*}$ & 0.215 & $\mathbf{1 . 0 0 0}$ & 0.220 & $-0,114$ \\
XD & -0.231 & -0.040 & $0.449^{*}$ & -0.040 & $0.684^{*}$ & $\mathbf{1 . 0 0 0}$ & 0.221 \\
RT & -0.152 & $-0.260^{*}$ & -0.050 & 0.044 & -0.240 & $0.685^{*}$ & $\mathbf{1 . 0 0 0}$ \\
\hline
\end{tabular}

*Significant according to T test (5\%) (significativo de acordo com o teste $\mathrm{T}(5 \%)$ ).

(1980) employing a set of ten genetically distinct carrot cultivars. These authors also found estimates for genotypic and phenotypic correlation for the traits root yield and root length of $95 \%$ and $87 \%$, respectively. Prasad \& Prasad (1978), employing a set of 20 genetically and geographically distinct cultivars obtained heritability values of $67 \%$ for average root length. Brar \& Sukhija (1981) reported heritability values for root length of $76 \%$. Likewise, Silva et al. (2009) reported heritability of 53 to $65 \%$. The relatively smaller heritability values obtained in the present study could be explained by the fact that a considerable amount of additive genetic variance for RL has been depleted during the development of this population.

Phenotypic and genotypic correlations among quantitative leaf and root traits among half-sib families derived from 'Alvorada' were overall low to intermediate indicating that major genetic factors controlling these traits are either independent or loosely linked. In addition, there is a possibility that pleiotropy might play a minor role in controlling expression of this set of traits. The matrices of phenotypic and genotypic correlations among families of half-sib families derived from 'Alvorada' for the traits RL, NL, LL, RW, RD, RT, CS, and XD indicated that selection of populations expressing multiple desirable agronomic and processing traits is possible employing this germplasm. However, it is important to highlight that there are much stronger phenotypic and genotypic correlations between the traits RW and RD $(0.56$ and 0.86 , respectively), than among other traits. The indication that the larger RD is associated with larger RW is in agreement with McCollum (1971) that found a correlation value of 0.87. Alves et al. (2004) estimated a correlation value of 0.54 between these traits in families derived from the original 'Brasília' cultivar, which agrees with Natarajam \& Arumagan (1980) that found out that RD and RW were positively correlated in carrot germplasm from India.

The path analysis allows an unfolding of simple correlation coefficients in direct and indirect effects, which provides a better understanding of the cause and effect relationships among traits. The strong association between RL and RW was confirmed by the high direct effect in path analysis (Table 3), this result agrees with Silva et al. (2009). The weak correlation between RL and NL was due to the indirect effect of RW, what is a strong 
Table 3. Path analysis of root length (RL) and the traits: number of leaves (NL), leaf length (LL), root mass (RW), xylem diameter (XD) and root tip (RT) in half-sib carrot families derived from the cultivar Alvorada evaluated in Brasília, Brazil [análise de trilha para comprimento de raiz (RL) de acordo com os caracteres: número de folhas (NL), comprimento de folha (LL), massa de raiz (RW), diâmetro de xilema (XD) e tipo de ponta de raiz (RT) em famílias de meios-irmãos de cenoura derivadas da cultivar Alvorada avaliadas em Brasília, Brasil]. Brasília, Embrapa Hortaliças, 2005.

\begin{tabular}{lccccccc}
\hline \multirow{2}{*}{ Traits } & \multicolumn{7}{c}{ Indirect effect* $^{*}$} \\
\cline { 2 - 7 } & $\mathbf{N L}^{3}$ & LL & RW & RD & XD & RT & Direct effect \\
\hline NL & & 0.006 & 0.408 & -0.083 & 0.111 & -0.048 & 0.026 \\
LL & 0.009 & & 0.184 & -0.112 & 0.017 & -0.083 & 0.021 \\
RW & 0.002 & 0.004 & & -0.263 & -0.215 & -0.016 & 0.900 \\
RD & 0.006 & 0.006 & 0.629 & & -0.170 & -0.067 & -0.378 \\
XD & -0.006 & -0.001 & 0.407 & -0.134 & & 0.218 & -0.480 \\
RT & -0.004 & -0.005 & -0.045 & 0.080 & -0.329 & & 0.318 \\
\hline
\end{tabular}

*Indirect effect of traits in the line (NL, LL, RW, RD, XD and RT) on the traits on the column [efeito dos caracteres da linha (NL, LL, RW, RD, XD e RT) nos caracteres da coluna]; **Direct effect of the traits on the column on root length (RL) [efeito direto dos caracteres da coluna em comprimento de raiz $(\mathrm{RL})] ; \mathrm{R}^{2}=0.75$.

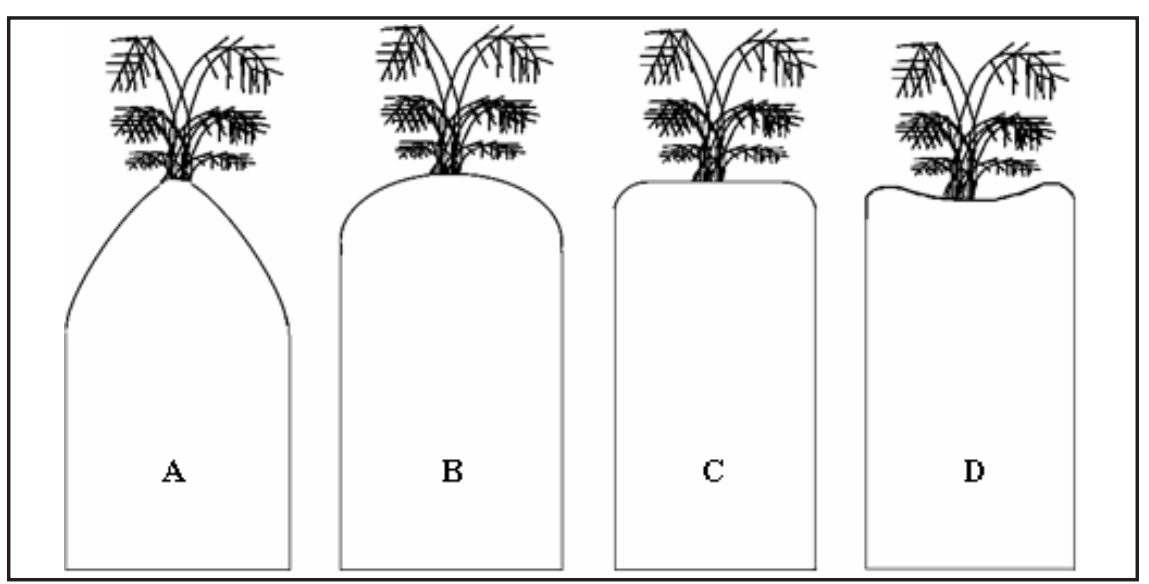

Figure 1. Crown shape: (A) conic, (B) round, (C) flat, and (D) concave [formato de ombro: (A) cônico, (B) arredondado, (C) plano, e (D) côncavo]. Brasília, Embrapa Hortaliças, 2005.

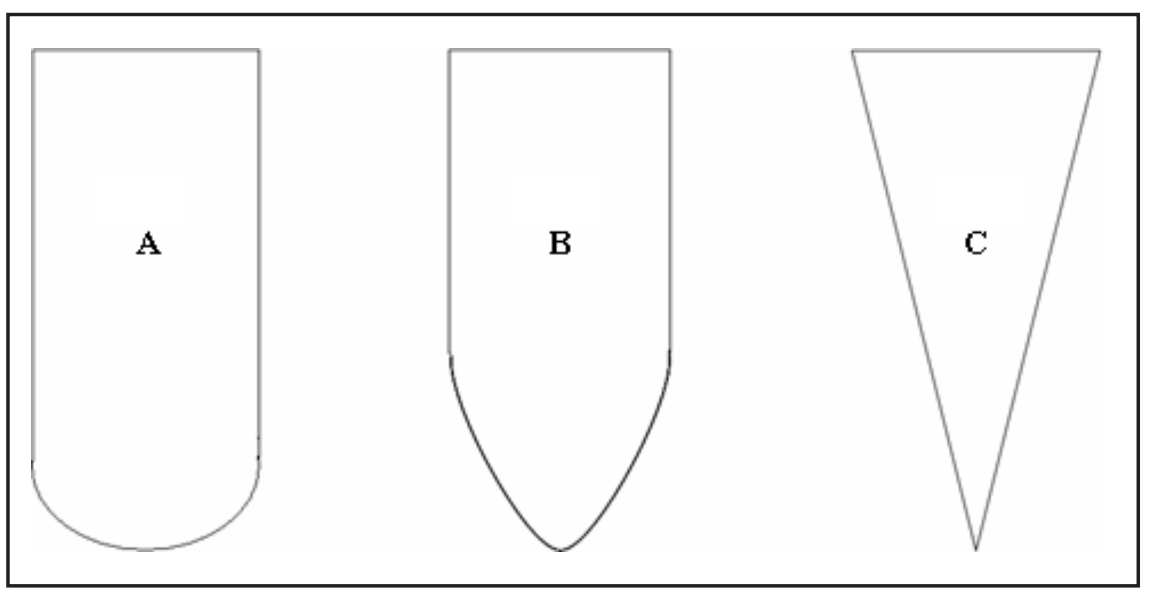

Figure 2. Root tip: (A) round, (B) slightly pointed, and (C) pointed [tipo de ponta de raiz: (A) arredondado, (B) levemente apontado, e (C) apontado]. Brasília, Embrapa Hortaliças, 2005. indication that these traits are not closely associated. The RD and XD displayed partial genetic correlation to each other and displayed negative direct effect on $\mathrm{RL}$, indicating that longer roots have smaller RD and smaller XD. The correlation analysis did not demonstrate this negative association due to the indirect effect of RW, which was found to be correlated with RD and XD. This result can be explained by the initial pattern of the carrot root growth, which is predominantly in length (White \& Strandberg, 1978). A more pronounced growth in diameter is observed only after this stage of development (Esau, 1940). Therefore, short roots would increase in diameter more quickly. In the analysis, after disinflation of the positive correlation effect observed between RT and XD, it was also possible to demonstrate that RT has positive direct effect on RL, with pointed roots tip (type $\mathrm{C}$ in Figure 2) having association with RL (0.32) (Table 3).

Carrot is one of the few vegetables of economic importance that accumulates appreciable amounts of the two most important provitamin A precursors, $\alpha$-carotene and $\beta$-carotene (Simon \& Wolff, 1987). 'Brasilia'-derived germplasm has been successfully cultivated in several tropical countries where vitamin A deficiency is still one of the most serious dietary problems. However, the genetic improvement of this germplasm for greater RL would be an outstanding additional step towards the development of a new generation of high-carotene tropical-adapted cultivars suitable for the cut and peel processing industry. The development of tropical-adapted high-carotene carrot cultivars would also be the basis for the expansion of the cut and peel processing industry in these areas. These highvalue added items would provide these regions with new opportunities for economic diversification and growth. The work reported here is the first initiative towards the establishment of a breeding platform that would allow the improvement of tropical carrots for multiple traits which is necessary for the development of cultivars suitable for the 
'baby-carrot' industry.

\section{REFERENCES}

ALVES JCS; PEIXOTO JR; VIEIRA JV; BOITEUX LS. 2004. Estimativas de parâmetros genéticos para um conjunto de caracteres de raiz e folhagem em populações de cenoura derivadas da cultivar Brasília. Horticultura Brasileira 22: 475-480.

BOITEUX LS; DELLA-VECCHIA PT; REIFSCHNEIDER FJB. 1993. Heritability estimate for resistance to Alternaria dauci in carrot. Plant Breeding 110: 165-167.

BRAR JS; SUKHIJA BS. 1981. Studies on genetic parameters in carrot (Daucus carota L.) Journal Research Punjab Agriculture University 18: 287-291.

CRUZ CD; REGAZZI AJ; CARNEIRO PCS. 2004. Modelos Biométricos Aplicados ao Melhoramento Genético. Universidade Federal de Viçosa - Imprensa Universitária, Viçosa, Minas Gerais, Brazil. 480p.

ESAU K. 1940. Developmental anatomy of the fleshy storage organ of Daucus carota. Hilgardia 13: 175-226.

LUCIER, G; LIN BH. 2007. Factors affecting carrot consumption in the United States. Outlook Report of the Economic Research Service/USDA, VGS319-01. Available at: www.ers.usda.gov/publications/ vgs/2007/03Mar/VGS31901/VGS31901.pdf

LUZ JMQ; CALÁBRIA IP; VIEIRA JV; MELO B; SANTANA DG; SILVA MAD. 2008. Densidade de plantio de cultivares de cenoura para processamento submetidas à adubações química e orgânica. Horticultura Brasileira 26: 276-280.

MCCOLLUM GD. 1971. Greening of carrot roots (Daucus carota L.): Estimates of heritability and correlation. Euphytica 20: 549-560.

NATARAJAN S; ARUMUGAN R. 1980. Association analysis of yield and its components in carrot (Daucus carota L.). Madras Agricultural Journal 67: 594-597.

NYQUIST WE. 1991. Estimation of heritability and prediction of selection response in plant populations. Critical Reviews in Plant Science 10: 235-322.

PRASAD A; PRASAD L. 1978. Genotypic and phenotypic variability in a collection of carrot varieties. Progressive Horticulture 11: 21-25.

SILVA GO; VIEIRA JV; VILELA MS. 2009. Seleção de caracteres de cenoura cultivada em dois sistemas de produção agroecológicos no Distrito Federal. Revista Ceres 56: 595-601.

SILVA GO; VIEIRA JV; NASCIMENTO WM. 2010. Estratégias de seleção para germinação de sementes de cenoura em alta temperatura. Revista Ceres 57: 60-65.

SIMOES AN; MOREIRA S; COSTA FB; ALMEIDA AR; SANTOS RHS; PUSCHMANN R. 2010. Populational density and harvest age of carrots for baby carrot manufacture. Horticultura Brasileira 28: 147-154.

SIMON PW. 2000. Domestication, historical development, and modern breeding of carrot. Plant Breeding Review 19: 157-190.
SIMON PW; WOLFF XY. 1987. Carotenes in typical and dark orange carrots. Journal of Agriculture and Food Chemistry 35: $1017-$ 1022.

SIMON PW; FREEMAN RE; VIEIRA JV; BOITEUX LS; BRIARD M; NOTHNAGEL T; MICHALIK B; KWON YS. 2008. Carrot. In: p.327-357. Handbook of Plant Breeding, Vegetables II. Fabaceae, Liliaceae, Solanaceae, and Umbelliferae, vol. 2. PROHENS J \& NUEZ F (eds). Springer, New York, New York, USA.

VIEIRA JV; DELLA VECHIA PT; IKUTA H. 1983. Cenoura 'Brasília'. Horticultura Brasileira 1: 42.

VIEIRA JV; CHARCHAR JM; ARAGÃO ASF; BOITEUX LS. 2003. Heritability and gain from selection for field resistance against multiple root-knot nematode species (Meloidogyne incognita race 1 and $M$. javanica) in carrot. Euphytica 130: 11-16.

VIEIRA JV; SILVA JBC; CHARCHAR JM; RESENDE FV; FONSECA MEN; CARVALHO AM; MACHADO CMM. 2005. Esplanada: cultivar de cenoura de verão para fins de processamento. Horticultura Brasileira 23: 851-852.

VILELA MS. 2008. Estimativas de parâmetros genéticos para caracteres de cenoura em sistemas de cultivo agroecológico. Brasília: UnB. 68p. (Tese mestrado).

WHITE JM; STRANDBERG JO. 1978. Early root growth of carrots in organic soil. Journal of American Society of Horticultural Science 103: 344-347. 